\title{
UPAYA PERBAIKAN SIFAT KIMIA LAHAN BEKAS TAMBANG EMAS DENGAN PEMBERIAN AMELIORAN TERHADAP PERTUMBUHAN KEDELAI DI KABUPATEN SIJUNJUNG
}

\author{
Giska Oktabriana. S*, Riza Syofiani \\ Prodi Agroteknologi, STIPER Sawahlunto Sijunjung \\ ${ }^{*}$ Email : giskaoktabriana@gmail.com
}

\begin{abstract}
Abstrak
Kabupaten Sijunjung merupakan daerah penghasil emas di Sumatera Barat. Aktivitas penambangan emas di daerah ini banyak dilakukan pada lahan pertanian, perkebunan dan di badan sungai. Penambangan emas yang dilakukan secara ilegal ini menyisakan lahan bekas tambang seluas 200 ha menjadi terbiar dan tidak produktif. Akibat yang ditimbulkan berupa kerusakan sifat fisik, kimia dan biologi tanah, seperti rendahnya daya pegang air, porositas besar, rendahnya kesuburan tanah, $\mathrm{pH}$ tanah masam, N-Total, P-tersedia, KTK tanah serta kandungan basa-basa (K, Ca, Mg dan $\mathrm{Na}$ ) yang rendah. Untuk memperbaiki sifat tanah ini dapat dilakukan dengan pemberian amelioran yang nantinya dapat menyumbangkan unsur hara bagi tanah. Tujuan penelitian ini yaitu untuk mengetahui dosis amelioran optimal dalam memperbaiki sifat kimia tanah. Penelitian ini dilakukan di Nagari Pala Luar Kecamatan Koto Tujuh Kabupaten Sijunjung selama 3 bulan dan dilanjutkan dengan analisis sifat kimia tanah di Laboratorium Tanah Fakultas Pertanian Universitas Andalas. Rancangan yang digunakan dalam penelitian ini adalah Rancangan Acak Kelompok (RAK) dengan 5 perlakuan dan 3 ulangan, dengan perlakuan $\mathrm{A}=$ Kontrol, $\mathrm{B}=0,5 \mathrm{~kg}$ jerami $+0,5 \mathrm{~kg}$ pukan sapi, $\mathrm{C}=1 \mathrm{~kg}$ jerami $+1 \mathrm{~kg}$ pukan sapi, $\mathrm{D}=1,5 \mathrm{~kg}$ jerami $+1,5 \mathrm{~kg}$ pukan sapi, $\mathrm{E}=2 \mathrm{~kg}$ jerami $+2 \mathrm{~kg}$ pukan sapi. Data analisis dengan menggunakan tabel Anova 5\% apabila $\mathrm{F}$ hitung lebih hitung lebih dari $\mathrm{F}$ tabel $5 \%$ dan uji lanjut BNJ 5\%.Dari hasil Penelitian dapat disimpulkan bahwa pemberian ameliorandapat memperbaiki sifat kimia tanah dan meningkatkan pertumbuhan kedelai di lahan bekas tambang emas.
\end{abstract}

Kata kunci : sifat kimia tanah, lahan bekas tambang, amelioran, kedelai

Sijunjung Regency is a gold-producing area in West Sumatra. Gold mining was carried out on agricultural land, plantations, and river bodies. This gold mining, which done illegally, leaves a former mining area of 200 ha that is unproductive and unproductive. The resulting damage was in the form of damage to the physical, chemical and biological properties of the soil, such as low water-holding power, large porosity, low soil fertility, acid soil $\mathrm{pH}, \mathrm{N}$-Total, $\mathrm{P}$-available, soil $\mathrm{CEC}$ and alkaline content $(\mathrm{K}, \mathrm{Ca}, \mathrm{Mg}$ and $\mathrm{Na}$ ) are low. To improve the properties of this soil, it can be done by providing ameliorants that can later contribute nutrients to the soil. The purpose of this study was to determine optimalization of ameliorant dosage in order to improving the soil properties. This research was conducted in Nagari Pala Luar, Koto Tujuh District, Sijunjung Regency for 3 months and continued with the analysis of soil chemical properties at the Soil Laboratory of the Faculty of Agriculture, Andalas University. The design used in this study was a randomized block design (RBD) with 5 treatments and 3 replications, with treatment $\mathrm{A}=$ Control, $\mathrm{B}=0.5 \mathrm{~kg}$ of straw $+0.5 \mathrm{~kg}$ of cow manure, $\mathrm{C}=1 \mathrm{~kg}$ of straw +1 $\mathrm{kg}$ of manure. cattle, $\mathrm{D}=1.5 \mathrm{~kg}$ of hay $+1.5 \mathrm{~kg}$ of cow manure, $\mathrm{E}=2 \mathrm{~kg}$ of straw $+2 \mathrm{~kg}$ of cow manure. Data analysis using the ANOVA table 5\% if $\mathrm{F}$ count is more than $\mathrm{F}$ table 
$5 \%$ and further test BNJ 5\%. From the results of the study, that can be concluded that the provision of amelioration can improve soil chemical properties and increase of soybeans growth in former gold mining areas.

Key words: soil chemical properties, ex-mining land, ameliorant, soybeans

\section{PENDAHULUAN}

Penambangan emas sekarang ini banyak dilakukan oleh masyarakat untuk memenuhi kebutuhan ekonomi mereka, salah satunya terjadi di Provinsi Sumatera Barat. Menurut laporan Dinas Pertambangan dan Energi Provinsi Sumatera Barat emas terdapat di kabupaten Sijunjung, 50 kota, Pasaman dan Pesisir selatan. Salah satu wilayah penambangan emas di kabupaten Sijunjung, yaitu di nagari Pala Luar kecamatan Koto Tujuh kabupaten Sijunjung.

Penambangan emas dilakukan dengan sistem tambang terbuka yang merupakan suatu tipe tambang dimana bahan galian berada jauh di dalam tanah dan dapat terjadi pada setiap kegiatan penggalian dan konstruksi (Adman et al., 2012). Pemakaian alat-alat berat pada kegiatan penambangan juga diketahui dapat mengakibatkan terdapatnya lubang-lubang besar bekas galian yang kedalamannya mencapai hingga 3-4 meter (Hasibuan, 2006).

Selain itu, kegiatan penambangan juga berpengaruh terhadap keseimbangan ekosistem permukaan tanah, menurunkan produktivitas tanah serta mutu lingkungan, permukaan lahan menjadi tidak teratur, kesuburan tanah rendah dan rawan erosi sehingga daya dukung tanah untuk tanaman menjadi rendah.

Pada umumnya lahan-lahan bekas penambangan memiliki kandungan hara makro yang sangat rendah, terutama kandungan $\mathrm{N}, \mathrm{P}, \mathrm{K}$, $\mathrm{Na}$, dan $\mathrm{Ca}$, serta tingkat kemasaman tanah $(\mathrm{pH})$ dan kapasitas tukar kation (KTK) yang rendah. Selain itu mikroorganisme tanah yang sangat membantu dalam stabilisasi struktur tanah, sumbangan mineral-mineral inorganik, ataupun sumbangannya dalam zat pengatur pertumbuhan, juga sangat rendah (Hetrick et al., 1994). Salah satu cara untuk memperbaiki kesuburan tanah bekas tambang emas yaitu dengan pemberian amelioran pada tanah.

Kedelai merupakan salah satu komoditas yang memiliki nilai ekonomis penting di Indonesia. Hal tersebut terkait dengan perannya sebagai sumber protein nabati yang relatif murah. Permintaannya mengalami tren yang meningkat, sementara produksi kedelai rendah sehingga belum dapat memenuhi permintaan tersebut. Produksi kedelai maksimal tahun 2010 sebanyak 962,540 ton, yang hanya mampu mencukupi sekitar 43\% dari kebutuhan nasional.

\section{BAHAN DAN METODE}

Penelitian ini dilakukan di Nagari Pala Luar Kecamatan Koto Tujuh Kabupaten Sijunjung selama 3 bulan dan dilanjutkan dengan analisis sifat kimia tanah di Laboratorium Tanah Fakultas Pertanian Universitas Andalas. Rancangan yang digunakan dalam penelitian ini adalah Rancangan Acak Kelompok (RAK) $5 \times 3$ dengan 5 perlakuan dan 3 ulangan, perlakuan penggunaan amelioran dimana :

$\mathrm{A}=$ Kontrol

$\mathrm{B}=0,5 \mathrm{~kg}$ jerami $+0,5 \mathrm{~kg}$ pukan sapi

$\mathrm{C}=1 \mathrm{~kg}$ jerami $+1 \mathrm{~kg}$ pukan sapi

$\mathrm{D}=1,5 \mathrm{~kg}$ jerami $+1,5 \mathrm{~kg}$ pukan sapi

$\mathrm{E}=2 \mathrm{~kg}$ jerami $+2 \mathrm{~kg}$ pukan sapi

Data analisis dengan menggunakan tabel Anova 5\% apabila $\mathrm{F}$ hitung lebih hitung lebih dari $\mathrm{F}$ tabel $5 \%$ dan uji lanjut BNJ $5 \%$.

\section{Pelaksanaan Penelitian \\ Pembuatan Amelioran dalam bentuk kompos}

Proses pembuatan kompos dimulai dengan mencincang jerami padi dengan 
mesin (chopper) sehingga berukuran 3-5 $\mathrm{cm}$ kemudian dicampur dengan pupuk kandang. Untuk mempercepat proses dekomposisi kompos ditambah dekomposer EM4. Jerami padi dan pupuk kandang diaduk hingga merata lalu ditumpuk di atas wadah inkubasi atau pemeraman (plastik hitam tebal) ditaruh dalam ruangan sehingga terhindar dari hujan.Setelah satu minggu, kompos dibolak balik atau diaduk kembali.Pemeraman selesai setelah 6-8 minggu.

\section{Persiapan lahan}

Persiapan lahan dimulai dengan penyiangan lahan tersebut dari gulma yang ada. Setelah penyiangan dilakukan pembuatan petak-petak percobaan dengan ukuran $2 \mathrm{~m} \times 3 \mathrm{~m}$ dengan tinggi $20 \mathrm{~cm}$ dan jarak antar petak $50 \mathrm{~cm}$.

\section{Pemberian perlakuan, inkubasi dan pengambilan sampel tanah}

Sebelum diberi perlakuan terlebih dahulu sampel tanah diambil untuk analisis awal sifat fisik dan kimia tanah. Sampel diambil dengan cara komposit pada kedalaman tanah $0-20$ $\mathrm{cm}$. Kompos diberikan sesuai dengan perlakuan yaitu dengan cara menebarkannya di atas permukaan bedengan kemudian diaduk sampai merata. Kemudian inkubasi selama 1 minggu. Pengambilan sampel tanah sesudah inkubasi dilakukan pada setiap petak perlakuan dengan cara yang sama dengan pengambilan sampel awal.

\section{Penanaman}

Penanaman kedelai dilakukan dengan cara ditugal dan memasukkan benih sebanyak 2 butir/lubang dengan jarak tanam $25 \times 25 \mathrm{~cm}$.

Tabel 1. Kadar hara kompos

\begin{tabular}{lcc} 
& Ciri Kimia & Hara Kompos \\
\hline C-Organik (\%) & 23,49 \\
N-Total (\%) & 2,45 \\
$\mathrm{P}_{2} \mathrm{O}_{5}(\%)$ & 58,63 \\
K-total (\%) & 0,82 \\
\hline
\end{tabular}

\section{Pemeliharaan}

Pemeliharaan yang dilakukan selama penelitian meliputi penyiraman, penyiangan dari gulma, dan pemberantasan hama penyakit. Penyiraman dilakukan 1 kali sehari apabila hari tidak hujan. Penyiangan gulma dilakukan dengan cara mencabut gulma yang tumbuh.

\section{Panen}

Panen dilakukan pada saat tanaman berumur \pm 80 hari. Ciri tanaman kedelai yang siap panen yaitu daunnya telah menguning dan mulai rontok, buah kedelai berwarna kuning kecoklatan, polong sudah padat berisi dan kelihatan retak-retak.

\section{Pengamatan}

\section{Pengamatan tanah}

Pengamatan tanah meliputi analisis sifat kimia tanah seperti $\mathrm{pH}, \mathrm{N}$ total, P-tersedia, K-dd, dan C-organik.

\section{Pengamatan tanaman}

Pengamatan tanaman yang dilakukan meliputi tinggi tanaman dan bobot 100 biji.

\section{HASIL DAN PEMBAHASAN}

\section{Hasil Analisis Hara Kompos}

Hasil analisis hara kompos dan ciriciri kimia kompos disajikan pada Tabel 1. yang memperlihatkan bahwa kompos membebaskan unsur hara N, P, K yang dibutuhkan tanaman. Pemberian kompos diharapkan dapat meningkatkan kandungan unsur hara $\mathrm{N}, \mathrm{P}, \mathrm{K}$ pada lahan bekas tambang emas dan dapat meningkatkan pertumbuhan kedelai. 
Analisis Sifat Kimia Tanah

a. Analisis tanah bekas tambang sebelum diberi amelioran
Hasil analisis sifat kimia lahan bekas tambang sebelum diberi amelioran dapat dilihat pada Tabel 2.

Tabel 2. Hasil analisis beberapa sifat kimia sebelum diberi amelioran

\begin{tabular}{lcc}
\hline \multicolumn{1}{c}{ Sifat Kimia Tanah } & Nilai & Kriteria*) \\
\hline $\mathrm{pH} \mathrm{H} \mathrm{H}_{2} \mathrm{O}$ & 5,18 & Masam \\
N-total (\%) & 0,15 & Rendah \\
P-tersedia (ppm) & 5,43 & Rendah \\
K-dd (me/100 g) & 0,18 & Rendah \\
C-organik (\%) & 0,80 & Sangat rendah \\
\hline
\end{tabular}

*) Staf Pusat Penelitian Tanah (1983 cit (Hardjowigeno, 2003)

Dari Tabel di atas dapat kita lihat bahwa sifat kimia lahan bekas tambang sebelum diberi amelioran pada umumnya memiliki $\mathrm{pH}$ yang masam dan kandungan hara yang juga tergolong sangat rendah.

\section{b. Analisis tanah setelah diberi} amelioran

Tabel 3. Pengaruh pemberian amelioran terhadap $\mathrm{pH}$ tanah dan P-tersedia pada lahan bekas tambang

\begin{tabular}{ccc}
\hline Perlakuan & \multicolumn{2}{c}{ Sifat dan ciri kimia tanah } \\
\cline { 2 - 3 } & $\mathrm{pH}$ & P-tersedia \\
\hline $\mathrm{A}$ & $5,29 \mathrm{~m}$ & $4,57 \mathrm{sr}$ \\
$\mathrm{B}$ & $6,32 \mathrm{am}$ & $6,45 \mathrm{r}$ \\
$\mathrm{C}$ & $6,21 \mathrm{~m}$ & $7,02 \mathrm{r}$ \\
$\mathrm{D}$ & $6,10 \mathrm{am}$ & $6,61 \mathrm{r}$ \\
E & $5,92 \mathrm{am}$ & $6,78 \mathrm{r}$ \\
\hline
\end{tabular}

Ket $: \mathrm{m}=$ masam, am = agak masam, $\mathrm{r}=$ rendah, $\mathrm{sr}=$ sangat rendah

Peningkatan nilai $\mathrm{pH}$ tanah secara angka pada tanah sejalan dengan meningkatnya kation-kation basa seperti K. Peningkatan $\mathrm{pH}$ tidak sama setiap perlakuan. Hal ini disebabkan karena berbedanya dosis kompos yang diberikan pada setiap perlakuan. Soepardi, (1983) menyatakan bahwa bahan organik dapat mengurangi kelarutan Al dengan membentuk senyawa komplek yang tidak larut, sehingga hidrolisis Al menghasilkan ion $\mathrm{H}$ berkurang dan mengakibatkan $\mathrm{pH}$ meningkat.

$$
\text { Peningkatan P-tersedia }
$$

disebabkan karena adanya sumbangan

\section{Analisis $\mathrm{pH} \quad \mathrm{H}_{2} \mathrm{O}$ dan $\mathrm{P}-$ tersedia tanah}

Hasil analisis $\mathrm{pH}$ tanah dan Ptersedia setelah diberi ameliorandan hasil penelitian dinilai berdasarkan kriteria disajikan pada Tabel 3. 
organik insitu berupa kompos dan hasil disajikan pada Tabel 4. penelitian dinilai berdasarkan kriteria Tabel 4. Pengaruh pemberian kompos pada lahan bekas tambang terhadap C-organik, Ntotal dan K-dd tanah

\begin{tabular}{cccc}
\hline \multirow{2}{*}{ Perlakuan } & \multicolumn{3}{c}{ Sifat dan ciri kimia tanah } \\
\cline { 2 - 4 } & C-organik & N-total & K-dd \\
\hline A & $2,78 \mathrm{sd}$ & $0,35 \mathrm{sd}$ & $0,42 \mathrm{sd}$ \\
B & $5,89 \mathrm{st}$ & $0,63 \mathrm{t}$ & $0,51 \mathrm{sd}$ \\
C & $6,54 \mathrm{st}$ & $1,03 \mathrm{st}$ & $0,58 \mathrm{sd}$ \\
D & $6,32 \mathrm{st}$ & $0,95 \mathrm{st}$ & $0,54 \mathrm{sd}$ \\
E & $5,18 \mathrm{st}$ & $0,75 \mathrm{st}$ & $0,48 \mathrm{sd}$ \\
\hline
\end{tabular}

Ket $: s d=$ sedang, $\mathrm{t}=$ tinggi, $\mathrm{st}=$ sangat tinggi

Kandungan C-Organik dalam tanah setelah diberi kompostergolong kedalam kriteria tinggi.Kandungan $\mathrm{C}$ organik pada tanah erat hubungannya dengan kandungan bahan organik dalam tanah.Tingginya kandungan C-organik pada tanah ini berasal dari amelioran yang diberikan kedalam tanah berupa kompos. Kandungan $\mathrm{N}$-total dalam tanah setelah diberi kompos tergolong kriteria tinggi.Meningkatnya kandungan $\mathrm{N}$ dibandingkan tanah awal disebabkan karena adanya sumbangan $\mathrm{N}$ dari kompos yang diberikan kedalam tanah. (Damanik, et al., 2011) menambahkan bahwa bahan organik mengandung protein (N-organik), selanjutnya dalam dekomposisi bahan organik protein akan dilapuki oleh jasad-jasad renik menjadi asam-asam amino, kemudian menjadi ammonium (NH4) dan nitrat (NO3) yang larut di dalam tanah. Proses penguraian asam nitrat menjadi amonium dalam tanah akan mampu meningkatkan kandungan Nitrogen.

Nitrogen yang banyak dari bahan organik akan secara perlahan masuk ke dalam tanah serta terjadinya perubahan pada bahan induk tanah bekas tambang emas. Kandungan K-dd setelah diberi kompos telah mengalami peningkatan dari kriteria rendah menjadi sedang. Kandungan $\mathrm{K}$ dalam tanah dipengaruhi oleh penambahan bahan organik ke dalam tanah. Penambahan bahan organik pada tanah secara berangsurangsur akan terdekomposisi yang selanjutnya akan menyediakan unsur hara dalam tanah. Gusnidar \& Prasetyo, (2008) menyatakan dekomposisi bahan organik yang menghasilkan asam-asam organik juga dapat meningkatkan ketersediaan $\mathrm{K}$ yang terdapat dalam tanah.

\section{Pengamatan Tanaman}

Pengaruh pemberian amelioran terhadap jumlah helaian daun dan panjang daun tanaman kedelai dapat dilihat pada Tabel 5 .

Tabel 5. Rata-rata jumlah helaian daun dan panjang daun tanaman kedelai pada BerbagaiPerlakuan

\begin{tabular}{ccc}
\hline Perlakuan & jumlah helaian daun (helai) & panjang daun $(\mathrm{cm})$ \\
\hline A & 9 & 6,88 \\
B & 10 & 6,74 \\
C & 10 & 7,27 \\
D & 10 & 7,16 \\
E & 12 & 9,07 \\
\hline
\end{tabular}

Dari Tabel diatas dapat dilihat bahwa rata-rata jumlah helaian daun terbanyak dan panjang daun secara statistik tidak berbeda nyata.Jumlah helaian daun terbanyak terdapat pada perlakuan E yaitu 12 helai. Hal ini disebabkan karena terpenuhinya kebutuhan tanaman akan unsur hara dan air, terpenuhinya unsur hara dan air akan bertambahnya jumlah helaian daun tanaman kedelai. Perbedaan jumlah helaian daun disebabkan peran dari 
pupuk kompos itu sendiri yaitu dapat memperbaiki sifat fisik tanah dengan adanya sumber unsur $\mathrm{N}$ dari kompos $(2,45 \%)$ yang menambah unsur hara dalam tanah.

Panjang daun terpanjang diperoleh angka tertinggi pada perlakuan E yaitu sepanjang $9,07 \mathrm{~cm}$. Hal ini disebabkan karena sejalan dengan jumlah helaian daun yang banyak terdapat pada perlakuan ini dan juga disebabkan oleh banyaknya pupuk yang diberikan ke tanah maka akan dapat meningkat jumlah unsur hara dalam tanah yang dapat dimanfaatkan tanaman untuk pertumbuhan vegetatifnya. Walaupun terdapat perbedaan panjang daun masing-masing perlakuan namun dari analisis statistik tidak terlihat pengaruh yang nyata untuk masing-masing perlakuan terhadap pertumbuhan daun tanaman kedelai dikarenakan daun-daun tersebut belum mencapai batas maksimal.

Terjadinya penambahan panjang daun sampai batas maksimal karena adanya maristem pada ujung daun yang senantiasa mengalami pembelahan, sehingga terjadi proses fotosintesis yang sempurna. Suprapto, (2001) menjelaskan bahwa banyaknya jumlah helaian daun, panjang daun dan lebar daun tergantung pada jenis kesuburan tanah.

\section{SIMPULAN}

1. Pemberian amelioran dapat memperbaiki sifat kimia lahan bekas tambang emas.

2. Pemberian amelioran berpengaruh terhadap pertumbuhan tanaman kedelai pada lahan bekas tambang emas.

\section{DAFTAR PUSTAKA}

Adman, B., Hendrarto, B., \& Sasongko, D. P. (2012). Pemanfaatan Jenis
Pohon Lokal Cepat Tumbuh Untuk Pemulihan Lahan Pascatambang Batubara (Studi Kasus Di Pt. Singlurus Pratama, Kalimantan Timur). Jurnal Ilmu Lingkungan, 10(1), 19. https://doi.org/10.14710/jil.10.1.19 $-25$

Damanik, M. M. B., Bachtiar, E. H., Fauzi,Sarifuddin, Hamidah, $\mathrm{H}$. (2011). Kesuburan Tanah dan Pemupukan. USU Press. Medan

Gusnidar, ., \& Prasetyo, T. B. (2008). Pemanfaatan Tithonia Diversifolia pada Tanah Sawah yang Dipupuk P Secara Starter terhadap Produksi serta Serapan Hara N, P, dan K Tanaman Padi. Journal of Tropical Soils, 13(3), 209-216. https://doi.org/10.5400/jts.2008.v1 3i3.209-216

Hardjowigeno, S. (2003). Ilmu Tanah. Jakarta. Akademi Persindo. 286 hal

Hasibuan, B. E. (2006). Pupuk dan Pemupukan. Usu Press, Medan

Hetrick BAD, Wilson GWT., F. D. (1994). The Influence of Mycorrhizal Symbiosis and fertilizers Amendements on Establishment of Vegetation In Heavy Metal Mine Spoil. Environmental Poluttion, 15(1), 171-179.

Soepardi, G. (1983). Sifat Dan Ciri Tanah (D. I. Tanah (ed.)). IPB. Bogor. 591 hal.

Suprapto. (2001). Bertanam Kedelai. Penebar Swadaya. Jakarta. 53 hal

Sutedjo, A. (2006). Mengenal Penyakit Melalui Pemeriksaan Laboratorium. 